\title{
Sodium Requirement for Muscovy Ducks in Housing $^{1}$
}

http://dx.doi.org/10.1590/1806-9061-2018-0936

\section{-Author(s)}

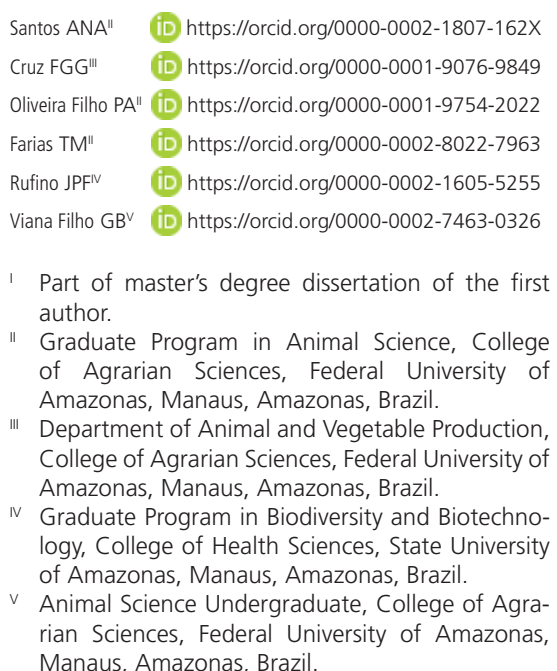

\section{-Mail Address}

Corresponding author e-mail address Frank George Guimarães Cruz

Federal University of Amazonas, South Sector, Universitary Campus, Av. General Rodrigo Octávio Jordão Ramos, 6200 , Coroado I, Manaus, Amazonas, Brazil, CEP 69077-000.

Phone: +55 92 3305-1181 (Ramal 4082)

Email: frankgcruz@gmail.com

\section{aKeywords}

Carcass traits, mineral, performance, poultry, waterfowl.

\section{ABSTRACT}

The present study aimed to determine the ideal sodium levels for muscovy ducks in housing. Two hundred and forty muscovy ducks of creole lineage were used, distributed in boxes with water and food ad libitum. The experimental design was completely randomized, where treatments were constituted by six nutritional plans (initial, growth and termination) with different sodium levels, and four replicates of 10 muscovy ducks each. The birds had weekly performance evaluations, and after 90 days, eight birds (four males and four females) in each treatment were slaughtered for evaluation of carcass traits. Data collected were subjected to Tukey test at $5 \%$ of significance. Differences were observed $(p<0.05)$ in performance (feed intake and feed conversion), where average levels of sodium presented better results. In carcass yields, average levels presented a positive influence $(p<0.05)$ on muscovy duck growth. Male muscovy ducks presented better feed efficiency than females in the same period. The present study indicates that nutritional plan 3 (initial $=0.25 \%$; growth $=0.30 \%$ and termination $=0.35 \%$ ) showed better nutritional requirements of sodium for muscovy ducks in housing, obtaining better performance and carcass development.

\section{INTRODUCTION}

Muscovy ducks provide several products for the poultry industry as meat, eggs, feathers for ornamental purposes, fatty livers and many others. There is a great market for all these products, but little explored in Latin America (Industrial Poultry, 2005; Rufino et al., 2015).

In Brazil, there aren't many companies that develop the Muscovy duck production. Only in the Brazilian southern region there are some companies that work in the production of ducks, muscovy ducks and their derivatives (Minas State Journal, 2015). The production in industrial scale is an unexplored area, especially due to the lack of technical information about appropriate nutritional requirements, facilities, and other factors that contribute for an ideal productive management (Feijó et al., 2016; Rufino et al., 2017).

Physiologically, like other birds, the muscovy ducks require small amounts of minerals to develop its vital functions in the organism (Pinheiro et al., 2011; Feijó et al., 2016; Costa, 2018). According to Borges (2001) and Borges et al. (2002), sodium, together with chlorine and potassium, present high metabolic activity in the acid-base balance and maintain the cellular osmotic pressure and metabolism of water in the tissues. These elements must be in constant balance so as not to compromise the good functioning of the enzymes responsible for several metabolic reactions in the animals. 
Sodium and chlorine are also sources of nutrients and improve the feed palatability, especially through $\mathrm{NaCl}$ supplementation (Borges et al., 1998). Sodium levels in diets significantly change the absorption of amino acids and simple carbohydrates by the gastrointestinal tract, changing indexes as weight gain and feed conversion (Guyton, 1985).

Considering the above, the present study aimed to determine ideal sodium levels for muscovy ducks in housing.

\section{MATERIAL AND METHODS}

This study was conducted in the facilities of the Poultry Sector, Department of Animal and Vegetable Production (DPAV), College of Agrarian Sciences (FCA), Federal University of Amazonas (UFAM), south sector of the University Campus, Manaus/AM, Brazil. The experimental procedures were approved by the Committee for Ethical Animal Use (CEUA - protocol number 027/2017) of the Federal University of Amazonas.
Two hundred muscovy ducks (Cairinamoschata domesticus) of creole lineage were used distributed in boxes with water and food ad libitum. The experimental design was completely randomized with the treatments constituted by five nutritional plans (initial, growth and termination)of sodium levels (Table 1) with four replicates of 10 muscovy ducks each.

Table 1 - Experimental sodium levels.

\begin{tabular}{lccc}
\hline \multirow{2}{*}{ Treatments } & \multicolumn{3}{c}{ Levels of Available Phosphorus (\%) } \\
\cline { 2 - 4 } & $\begin{array}{c}\text { Initial } \\
(1-35 \text { days })\end{array}$ & $\begin{array}{c}\text { Growth } \\
(36-70 \text { days })\end{array}$ & $\begin{array}{c}\text { Termination } \\
(71-90 \text { days })\end{array}$ \\
\hline Nut. Plan 1 & 0.35 & 0.40 & 0.45 \\
Nut. Plan 2 & 0.30 & 0.35 & 0.40 \\
Nut. Plan 3 & 0.25 & 0.30 & 0.35 \\
Nut. Plan 4 & 0.20 & 0.25 & 0.30 \\
Nut. Plan 5 & 0.15 & 0.20 & 0.25 \\
\hline
\end{tabular}

Experimental diets (Table 2) were calculated according to reference values provided by Rostagno et al. (2011), except energy and protein (Rufino et al., 2015), calcium (Feijó et al., 2016) and available phosphorus (Costa, 2018) that used ideal requirements for muscovy ducks.

Table 2 - Ingredients and nutritional composition of experimental diets.

\begin{tabular}{|c|c|c|c|c|c|c|c|c|c|c|c|c|c|c|c|}
\hline \multirow{3}{*}{$\begin{array}{l}\text { Diets }^{4} \\
\text { Ingredients }\end{array}$} & \multicolumn{15}{|c|}{ Nutritional plans with different levels of sodium for muscovy ducks } \\
\hline & \multicolumn{3}{|c|}{------- Plan 1 ------- } & \multicolumn{3}{|c|}{------- Plan 2 ------- } & \multicolumn{3}{|c|}{------- Plan 3 ------ } & \multicolumn{3}{|c|}{------ Plan 4 ------ } & \multicolumn{3}{|c|}{------- Plan 5 ------ } \\
\hline & Ini. & Gro. & Term. & Ini. & Gro. & Term. & Ini. & Gro. & Term. & Ini. & Gro. & Term. & Ini. & Gro. & Term. \\
\hline Corn $7.88 \%$ & 56.119 & 64.529 & 67.396 & 56.379 & 64.789 & 67.659 & 56.639 & 65.048 & 67.917 & 56.898 & 65.307 & 68.177 & 57.157 & 65.567 & 68.437 \\
\hline Soybean meal $46 \%$ & 36.567 & 28.392 & 24.580 & 36.522 & 28.347 & 24.532 & 36.477 & 28.302 & 24.487 & 36.432 & 28.257 & 24.442 & 36.387 & 28.212 & 24.397 \\
\hline Soybean oil & 1.989 & 1.955 & 2.968 & 1.901 & 1.867 & 2.880 & 1.812 & 1.779 & 2.792 & 1.724 & 1.691 & 2.704 & 1.636 & 1.602 & 2.615 \\
\hline Dicalcium phosphate & 2.896 & 2.426 & 2.191 & 2.896 & 2.425 & 2.191 & 2.896 & 2.425 & 2.191 & 2.895 & 2.425 & 2.190 & 2.895 & 2.424 & 2.190 \\
\hline Limestone & 1.023 & 1.109 & 1.150 & 1.023 & 1.109 & 1.150 & 1.023 & 1.109 & 1.151 & 1.024 & 1.109 & 1.151 & 1.024 & 1.110 & 1.151 \\
\hline Salt & 0.834 & 0.960 & 1.087 & 0.708 & 0.834 & 0.961 & 0.582 & 0.708 & 0.835 & 0.456 & 0.582 & 0.709 & 0.330 & 0.456 & 0.583 \\
\hline Vit./Mineral Supplement & $0.500^{1}$ & $0.500^{2}$ & $0.500^{3}$ & $0.500^{1}$ & $0.500^{2}$ & $0.500^{3}$ & $0.500^{1}$ & $0.500^{2}$ & $0.500^{3}$ & $0.500^{1}$ & $0.500^{2}$ & $0.500^{3}$ & $0.500^{1}$ & $0.500^{2}$ & $0.500^{3}$ \\
\hline DL-Methionine 99\% & 0.072 & 0.129 & 0.128 & 0.071 & 0.129 & 0.127 & 0.071 & 0.129 & 0.127 & 0.071 & 0.129 & 0.127 & 0.071 & 0.129 & 0.127 \\
\hline Total & 100 & 100 & 100 & 100 & 100 & 100 & 100 & 100 & 100 & 100 & 100 & 100 & 100 & 100 & 100 \\
\hline \multicolumn{16}{|l|}{ Nutritional Levels ${ }^{5}$} \\
\hline Met. energy, kcal/kg & 2,900 & 3,000 & 3,100 & 2,900 & 3,000 & 3,100 & 2,900 & 3,000 & 3,100 & 2,900 & 3,000 & 3,100 & 2,900 & 3,000 & 3,100 \\
\hline Crude Protein, \% & 21.000 & 18.000 & 16.500 & 21.000 & 18.000 & 16.500 & 21.000 & 18.000 & 16.500 & 21.000 & 18.000 & 16.500 & 21.000 & 18.000 & 16.500 \\
\hline Met. + cystine, \% & 0.720 & 0.705 & 0.664 & 0.720 & 0.705 & 0.664 & 0.720 & 0.705 & 0.664 & 0.720 & 0.705 & 0.664 & 0.720 & 0.705 & 0.664 \\
\hline Methionine, \% & 0.498 & 0.402 & 0.382 & 0.498 & 0.402 & 0.382 & 0.498 & 0.402 & 0.382 & 0.498 & 0.402 & 0.382 & 0.498 & 0.402 & 0.382 \\
\hline Calcium, \% & 1.250 & 1.100 & 1.050 & 1.250 & 1.100 & 1.050 & 1.250 & 1.100 & 1.050 & 1.250 & 1.100 & 1.050 & 1.250 & 1.100 & 1.050 \\
\hline Available phosphorus, \% & 0.650 & 0.550 & 0.500 & 0.650 & 0.550 & 0.500 & 0.650 & 0.550 & 0.500 & 0.650 & 0.550 & 0.500 & 0.650 & 0.550 & 0.500 \\
\hline Sodium, \% & 0.350 & 0.400 & 0.450 & 0.300 & 0.350 & 0.400 & 0.250 & 0.300 & 0.350 & 0.200 & 0.250 & 0.300 & 0.150 & 0.200 & 0.250 \\
\hline
\end{tabular}

1 Vit./mineral supplement - initial - content in 1 kg = Folic Acid 800 mg, Pantothenic Acid 12,500 mg, Antioxidant 0.5 g, Biotin 40 mg, Niacin 33,600 mg, Selenium 300 mg, Vit. A 6,700,000 UI, Vit. B1 1,750 mg, Vit. B12 9,600 mcg, Vit. B2 4,800 mg, Vit. B6 2,500 mg, Vit. D3 1,600,000 UI, Vit. E 14,000 mg, Vit. K3 1,440 mg. Mineral supplement - content in 0.5 kg = Manganese $150,000 \mathrm{mg}$, Zinc 100,000 mg, Iron 100,000 mg, Copper 16,000 mg, lodine 1,500 mg.

${ }^{2}$ Vit./mineral supplement - growth - content in $1 \mathrm{~kg}=$ Folic Acid $650 \mathrm{mg}$, Pantothenic Acid 10,400 mg, Antioxidant $0.5 \mathrm{~g}$, Niacin 28,000 mg, Selenium 300 mg, Vit. A 5,600,000 UI, Vit. B1 0.550 mg, Vit. B12 8,000 mcg, Vit. B2 4,000 mg; Vit. B6 2,080 mg, Vit. D3 1,200,000 UI, Vit. E 10,000 mg, Vit. K3 1,200 mg. Mineral supplement - content in 0.5 kg = Manganese 150,000 $\mathrm{mg}$, Zinc 100,000 mg, Iron 100,000 mg, Copper 16,000 mg, lodine 1,500 mg.

${ }^{3}$ Vit./mineral supplement - termination - content in $1 \mathrm{~kg}=$ Pantothenic Acid 7,070 mg, Antioxidant 0.5 g, Niacin 20,400 mg, Selenium 200 mg, Vit. A 1,960,000 UI, Vit. B12 4,700 mcg, Vit. B2 2,400 mg, Vit. D3 550,000 UI, Vit. E 5,500 mg, Vit. K3 $550 \mathrm{mg}$. Mineral supplement - content in 0.5 kg = Manganese 150,000 mg, Zinc 100,000 mg, Iron 100,000 mg, Copper 16,000 $\mathrm{mg}$, lodine $1,500 \mathrm{mg}$.

${ }^{4}$ Ini. = Initial; Gro. = Growth; Term. = Termination

${ }^{5}$ Estimated levels in Dry Matter 
The birds started the experimental period with one day of age and were evaluated at 90 days. For performance, the feed intake ( $\mathrm{kg} / \mathrm{bird})$, weight gain $(\mathrm{kg} / \mathrm{bird})$ and feed conversion $(\mathrm{kg} / \mathrm{kg})$ were analysed. Due to extreme difficulty of performing the sexing of muscovy ducks with one day, and the lack of technique for this (Rufino et al., 2017), performance was measured in mixed lots (birds with both sex in the same box).

At 90 days of age, already with an evident sexual dimorphism, after 12 hours of fasting, eight birds of each treatment (four males and four females) were randomly selected, identified and weighed. Next, these were electrically stunned $(40 \mathrm{~V} ; 50 \mathrm{~Hz})$ and slaughtered by cut of the jugular vein. The carcasses were immersed into hot water $\left(60^{\circ} \mathrm{C}\right.$ for $\left.62 \mathrm{~s}\right)$, plucked and eviscerated according to Mendes \& Patricio's (2004) recommendations, and the carcass yield was determined. Edible viscera (heart, gizzard, pro-ventricle and liver) were individually weighed.

Breast and leg (thigh + drumstick) samples were collected to measure $\mathrm{pH}$ and physical measurements (length, height and width). The commercial cuts (neck, breast, wing, back, thigh and drumstick) were separated according to Gomide et al. (2012) and measured by weighing in analytical balance $0.01 \mathrm{~g}$.

Statistical analysis was performed using the software Statistical Analysis System (2008) and estimates of the treatments were subjected to Tukey test at $5 \%$ of significance.

\section{RESULTS}

The results of performance are present in Table 3. Differences were observed $(p<0.05)$ for feed intake and feed conversion. Average levels of sodium in the diets (Nutritional Plan 3) presented better results.

Table 3 - Performance of muscovy ducks in housing fed nutritional plans with different sodium levels.

\begin{tabular}{lccc}
\hline \multirow{2}{*}{ Nutritional Plans } & \multicolumn{3}{c}{ Variables } \\
\cline { 2 - 4 } & $\begin{array}{c}\text { Feed intake } \\
(\mathrm{kg})\end{array}$ & $\begin{array}{c}\text { Weight gain } \\
(\mathrm{kg})\end{array}$ & $\begin{array}{c}\text { Feed conversion } \\
(\mathrm{kg} / \mathrm{kg})\end{array}$ \\
\hline Nut. Plan 1 & $9.84^{\mathrm{b}}$ & 2.16 & $4.58^{\mathrm{b}}$ \\
\hline Nut. Plan 2 & $9.41^{\mathrm{ab}}$ & 2.12 & $4.45^{\mathrm{ab}}$ \\
Nut. Plan 3 & $8.51^{\mathrm{a}}$ & 2.02 & $4.24^{\mathrm{a}}$ \\
Nut. Plan 4 & $9.84^{\mathrm{b}}$ & 2.19 & $4.60^{\mathrm{b}}$ \\
Nut. Plan 5 & $9.38^{\mathrm{ab}}$ & 2.42 & $4.89^{\mathrm{c}}$ \\
\hline$p$-value & $0.05^{*}$ & $0.10^{\mathrm{n}}$ & $0.04^{*}$ \\
\hline CV (\%) & 8.41 & 12.98 & 14.03 \\
\hline
\end{tabular}

$\mathrm{CV}$ - Coefficient of variation; * Significant effect $(p<0.05)$; ns - non significant effect.

The results of carcass traits are present in table 4. Differences $(p<0.05)$ were observed for slaughter weight among nutritional plans and sexes, and for foot, abdominal fat, liver, heart, gizzard and proventricle only among sexes.

Birds fed nutritional plans with higher sodium levels showed better carcass results (Nutritional plans 1 at 3). Male muscovy ducks presented better development of carcass, with great difference in the development of carcass among sexes. There was no interaction ( $p>0.05)$ between factors.

Table 4 - Slaughter weight (SW), carcass yield (CY), feathers (FE), foot (FT), abdominal fat (AF), liver (LV), heart (HT), gizzard (GZ) and pro-ventricle (PV) of muscovy ducks in housing fed nutritional plans with different levels of available phosphorus.

\begin{tabular}{|c|c|c|c|c|c|c|c|c|c|}
\hline \multirow[b]{2}{*}{ Factors } & \multicolumn{9}{|c|}{ Variables } \\
\hline & $\begin{array}{l}\text { SW } \\
(\mathrm{kg})\end{array}$ & $\begin{array}{l}C Y \\
(\%)\end{array}$ & $\begin{array}{l}\mathrm{FE} \\
(\%)\end{array}$ & $\begin{array}{c}\mathrm{FT} \\
(\%)\end{array}$ & $\begin{array}{c}\text { AF } \\
(\%)\end{array}$ & $\begin{array}{l}\text { LV } \\
\text { (g) }\end{array}$ & $\begin{array}{l}\mathrm{HT} \\
\text { (g) }\end{array}$ & $\begin{array}{l}G Z \\
(g)\end{array}$ & $\begin{array}{l}\text { PV } \\
\text { (g) }\end{array}$ \\
\hline \multicolumn{10}{|l|}{ Nut. Plans } \\
\hline Nut. Plan 1 & $2.58^{\mathrm{a}}$ & 6414 & 14.79 & 3.12 & 0.93 & 33.12 & 51.00 & 11.50 & 17.75 \\
\hline Nut. Plan 2 & $2.44^{\mathrm{ab}}$ & 65.76 & 14.72 & 2.89 & 0.73 & 33.37 & 58.00 & 9.50 & 16.25 \\
\hline Nut. Plan 3 & $2.42^{\mathrm{ab}}$ & 65.74 & 14.87 & 2.82 & 0.81 & 33.62 & 57.00 & 10.00 & 18.00 \\
\hline Nut. Plan 4 & $2.30^{\mathrm{b}}$ & 6730 & 16.10 & 2.90 & 0.64 & 33.12 & 50.25 & 10.62 & 19.00 \\
\hline Nut. Plan 5 & $2.33^{b}$ & 67.39 & 13.98 & 2.84 & 0.81 & 33.62 & 64.00 & 11.12 & 18.75 \\
\hline \multicolumn{10}{|l|}{ Sexes } \\
\hline Male & $3.10^{a}$ & 66.14 & 14.95 & $3.05^{a}$ & $0.55^{b}$ & $42.55^{a}$ & $66.90^{a}$ & $12.15^{\mathrm{a}}$ & $23.05^{a}$ \\
\hline Female & $1.73^{b}$ & 65.99 & 14.83 & $2.78^{b}$ & $1.01^{\mathrm{a}}$ & $26.20^{b}$ & $45.20^{b}$ & $8.95^{b}$ & $12.85^{b}$ \\
\hline Effect & \multicolumn{9}{|c|}{$p$-value } \\
\hline Nut. Plans & $0.03^{*}$ & $0.43^{\text {ns }}$ & $0.84^{\mathrm{ns}}$ & $0.53^{\text {ns }}$ & $0.52^{\text {ns }}$ & $0.79^{\text {ns }}$ & $0.21^{\mathrm{ns}}$ & $0.62^{\text {ns }}$ & $0.28^{\text {ns }}$ \\
\hline Sexes & $0.01^{* *}$ & $0.90^{\text {ns }}$ & $0.91^{\text {ns }}$ & $0.01^{* *}$ & $0.01^{* *}$ & $0.01^{* *}$ & $0.01^{* *}$ & $0.01^{* *}$ & $0.01^{* *}$ \\
\hline Interaction & $0.23^{\text {ns }}$ & $0.25^{\mathrm{ns}}$ & $0.30^{\mathrm{ns}}$ & $0.33^{\mathrm{ns}}$ & $0.35^{\text {ns }}$ & $0.45^{\text {ns }}$ & $0.28^{\text {ns }}$ & $0.32^{\text {ns }}$ & $0.34^{\mathrm{ns}}$ \\
\hline CV (\%) & 7.15 & 5.82 & 14.52 & 12.79 & 13.14 & 19.31 & 23.09 & 26.83 & 14.80 \\
\hline
\end{tabular}

$\mathrm{CV}$ - Coefficient of variation; " Significant effect $(P<0.05) ;{ }^{* *}$ Significant effect $(p<0.01)$; ns - non-significant effect. 
The results of commercial cuts are present in table 5. Differences $(p<0.05)$ were observed for \%neck, $\%$ breast, \%wing and \%thigh among nutritional plans and sexes, and for \%drumstick only among sexes.

The sodium levels directly influenced the development of carcass and its distribution in the commercial cuts. In general, birds fed nutritional plans 3 presented better results. Male muscovy ducks presented large carcass development, except \%wing and \%back. There was no interaction $(p>0.05)$ between factors.

The results of $\mathrm{pH}$ and physical measurements are present in table 6 . Differences $(p<0.05)$ were observed among nutritional plans for length, width and height

Table 5 - Commercial cuts of muscovy ducks in housing fed nutritional plans with different levels of available phosphorus.

\begin{tabular}{|c|c|c|c|c|c|c|}
\hline \multirow[b]{2}{*}{ Factors } & \multicolumn{6}{|c|}{ Variables } \\
\hline & $\begin{array}{l}\text { Neck } \\
(\%)\end{array}$ & $\begin{array}{c}\text { Breast } \\
(\%)\end{array}$ & $\begin{array}{l}\text { Wing } \\
(\%)\end{array}$ & $\begin{array}{l}\text { Thigh } \\
(\%)\end{array}$ & $\begin{array}{c}\text { Drumstick } \\
(\%)\end{array}$ & $\begin{array}{l}\text { Back } \\
(\%)\end{array}$ \\
\hline \multicolumn{7}{|l|}{ Nut. Plans } \\
\hline Nut. Plan 1 & $11.08^{b}$ & $17.78^{\mathrm{bc}}$ & $11.79^{c}$ & $10.10^{\mathrm{a}}$ & 26.62 & 22.63 \\
\hline Nut. Plan 2 & $10.62^{b c}$ & $18.04^{b}$ & $12.03^{b}$ & $10.01^{a}$ & 25.60 & 23.70 \\
\hline Nut. Plan 3 & $12.20^{\mathrm{a}}$ & $18.72^{\mathrm{ab}}$ & $13.14^{\mathrm{a}}$ & $8.85^{c}$ & 23.84 & 23.25 \\
\hline Nut. Plan 4 & $11.48^{\mathrm{ab}}$ & $18.80^{\mathrm{a}}$ & $12.93^{\mathrm{ab}}$ & $9.01^{b}$ & 24.96 & 22.82 \\
\hline Nut. Plan 5 & $11.47^{\mathrm{ab}}$ & $18.07^{b}$ & $12.16^{\mathrm{b}}$ & $9.43^{a b}$ & 25.68 & 23.19 \\
\hline \multicolumn{7}{|l|}{ Sexes } \\
\hline Male & $11.77^{a}$ & $18.40^{\mathrm{a}}$ & $12.78^{b}$ & $9.93^{a}$ & $26.99^{a}$ & 20.13 \\
\hline Female & $10.98^{b}$ & $18.16^{b}$ & $17.44^{\mathrm{a}}$ & $9.03^{b}$ & $23.69^{b}$ & 20.70 \\
\hline Effect & \multicolumn{6}{|c|}{$p$-value } \\
\hline Nut. Plans & $0.03^{*}$ & $0.03^{*}$ & $0.05^{*}$ & $0.02^{*}$ & $0.41^{\text {ns }}$ & $0.47^{\text {ns }}$ \\
\hline Sexes & $0.05^{*}$ & $0.05^{*}$ & $0.03^{*}$ & $0.04^{*}$ & $0.01^{* *}$ & $0.09^{\text {ns }}$ \\
\hline Interaction & $0.25^{\mathrm{ns}}$ & $0.26^{\mathrm{ns}}$ & $0.59^{\text {ns }}$ & $0.65^{\mathrm{ns}}$ & $0.35^{\mathrm{ns}}$ & $0.46^{\text {ns }}$ \\
\hline CV (\%) & 13.58 & 5.02 & 9.17 & 15.45 & 11.42 & 15.13 \\
\hline
\end{tabular}

$C V$ - Coefficient of variation; " Significant effect $(P<0.05) ;{ }^{* *}$ Significant effect $(p<0.01)$; ns - non-significant effect.

of breast, and length and $\mathrm{pH}$ of the leg. Differences $(p<0.05)$ were observed among sexes for length, width and height of breast and leg.

Birds fed diets with higher sodium levels presented better breast and leg development. Nutritional plans with lower levels of sodium presented worse development and lower $\mathrm{pH}$ values. Male muscovy ducks presented large size of breast and leg, with great difference in the development of carcass among sexes. There was no interaction ( $p>0.05$ ) between factors.

Table 6 - Physical measurements of breast and leg (thigh + drumstick) of muscovy ducks in housing fed nutritional plans with different levels of available phosphorus.

\begin{tabular}{|c|c|c|c|c|c|c|c|c|}
\hline \multirow{3}{*}{ Factors } & \multicolumn{8}{|c|}{ Variables } \\
\hline & \multicolumn{4}{|c|}{ Breast } & \multicolumn{4}{|c|}{ Leg (thigh + drumstick) } \\
\hline & $\begin{array}{l}\text { Length } \\
(\mathrm{cm})\end{array}$ & $\begin{array}{l}\text { Width } \\
(\mathrm{cm})\end{array}$ & $\begin{array}{l}\text { Height } \\
(\mathrm{cm})\end{array}$ & $\mathrm{pH}$ & $\begin{array}{l}\text { Lenght } \\
(\mathrm{cm})\end{array}$ & $\begin{array}{l}\text { Width } \\
(\mathrm{cm})\end{array}$ & $\begin{array}{l}\text { Height } \\
(\mathrm{cm})\end{array}$ & $\mathrm{pH}$ \\
\hline \multicolumn{9}{|l|}{ Nut. Plans } \\
\hline Nut. Plan 1 & $20.18^{a}$ & $13.75^{\mathrm{a}}$ & $3.68^{b}$ & 6.61 & $15.31^{\mathrm{a}}$ & 10.37 & 2.31 & $6.56^{a}$ \\
\hline Nut. Plan 2 & $19.93^{\mathrm{ab}}$ & $12.12^{\mathrm{ab}}$ & $3.75^{\mathrm{ab}}$ & 6.68 & $15.00^{\mathrm{ab}}$ & 9.06 & 2.75 & $6.55^{a}$ \\
\hline Nut. Plan 3 & $18.02^{b}$ & $11.93^{\mathrm{ab}}$ & $3.93^{\mathrm{ab}}$ & 6.54 & $15.25^{\mathrm{ab}}$ & 9.56 & 2.93 & $6.50^{a b}$ \\
\hline Nut. Plan 4 & $18.50^{\mathrm{b}}$ & $11.93^{\mathrm{ab}}$ & $4.62^{\mathrm{ab}}$ & 6.51 & $14.87^{\mathrm{ab}}$ & 9.06 & 3.06 & $6.48^{a b}$ \\
\hline Nut. Plan 5 & $18.00^{b}$ & $11.68^{b}$ & $4.87^{a}$ & 6.48 & $14.06^{b}$ & 9.37 & 2.87 & $6.39^{b}$ \\
\hline \multicolumn{9}{|l|}{ Sexes } \\
\hline Male & $21.02^{a}$ & $13.57^{a}$ & $4.67^{a}$ & 6.59 & $16.35^{a}$ & $10.52^{\mathrm{a}}$ & $3.00^{a}$ & 6.61 \\
\hline Female & $16.05^{b}$ & $11.00^{\mathrm{b}}$ & $3.67^{b}$ & 6.54 & $13.45^{b}$ & $8.45^{b}$ & $2.57^{b}$ & 6.58 \\
\hline Effect & \multicolumn{8}{|c|}{$p$-value } \\
\hline Nut. Plans & $0.01^{* *}$ & $0.02^{* \star}$ & $0.01^{*}$ & $0.16^{\mathrm{ns}}$ & $0.04^{*}$ & $0.09^{\text {ns }}$ & $0.12^{\text {ns }}$ & $0.01^{* *}$ \\
\hline Sexes & $0.01^{* *}$ & $0.01^{* \star}$ & $0.01^{*}$ & $0.32^{\text {ns }}$ & $0.01^{* *}$ & $0.01^{* *}$ & $0.02^{* *}$ & $0.74^{\text {ns }}$ \\
\hline Interaction & $0.12^{\mathrm{ns}}$ & $0.28^{\mathrm{ns}}$ & $0.06^{\mathrm{ns}}$ & $0.15^{\mathrm{ns}}$ & $0.14^{\mathrm{ns}}$ & $0.25^{\mathrm{ns}}$ & $0.07^{\mathrm{ns}}$ & $0.19^{\text {ns }}$ \\
\hline CV (\%) & 6.76 & 10.81 & 17.88 & 2.63 & 5.92 & 10.90 & 20.84 & 1.67 \\
\hline
\end{tabular}

CV - Coefficient of variation; " Significant effect $(P<0.05) ;{ }^{* *}$ Significant effect $(p<0.01) ;$ ns - non-significant effect. 


\section{DISCUSSION}

In our study, mean levels of sodium (nutritional plan 3) provided regulation of intake and better use of nutrients (feed conversion). However, these nutritional levels were higher than the requirement for broilers (Rostagno et al., 2017). According Feijó et al. (2016), higher mineral requirements for muscovy ducks are attributed by its greater carcass conformation and bone structure, larger than broilers.

Pulls (1988) and Guyton \& Hall (1997) observed that unbalance in the requirement of sodium in the diets results in the absorption of amino acids and monosaccharides by the gastrointestinal tract, whose transport is highly dependent of sodium and potassium bomb, directly affecting weight gain and feed conversion. According to Dean et al. (1973), ducks and muscovy ducks are very sensitive to sodium deficiency, with levels below the minimum recommendation and can cause mortality of more than $60 \%$.

When salt deficiency occurs in diets, sodium is the major limiting mineral, especially due to its lower concentration than chlorine in most of the ingredients (Andriguetto et al., 1990). Rosado (1988) comments that the highest concentration of sodium in the animal body is present in the extracellular fluid, containing on average $0.12 \%$.

According to Pinheiro (2009), Rostagno et al. (2011) and Rostagno et al. (2017), birds for meat production (broilers, ducks or muscovy ducks), present higher mineral requirement due to its large and fast body development, with ideal levels according to phase and profile of nutritional plan used.

These results reflected on carcass traits, observing that the average sodium presented a positive influence on muscovy ducks growth, with these levels above the recommendation for broilers (Rostagno et al., 2017), similar results were observed by Feijó et al. (2016) and Costa (2018), that also observed mineral requirement for muscovy ducks above the recommendation for broilers.

Patience (1990) comments that the acid-base balance may directly influence the growth, appetite, bone development, responses to thermal stress, and the metabolism of nutrients as amino acids, minerals and vitamins. And when this balance or $\mathrm{pH}$ of the birds' body fluids has a significant change, an acidosis or an alkalosis can occur, damaging the functionality of enzymes and other several tools of organism.

Our results also presented a great difference between male and female carcass, with males presenting larger carcasses than females. According to Gois et al. (2012), males present a better feed efficiency than females in the same period, with better results in weight gain, slaughter weight, \%feathers, \% feet and edible viscera.

Yakubu (2010), Gois et al. (2012) and Almeida (2016) comment that a natural sexual dimorphism for muscovy ducks exists, with mean weight of $3.80 \mathrm{~kg}$ for males and $2.22 \mathrm{~kg}$ for females. But, Drumond et al. (2013) and Almeida (2016) affirm that females present a precocious growth, reaching the adult weight faster, better distribution of commercial cuts and faster ideal carcass fat deposition (Vieira,1999), even having a lower final weight.

The sex is one of the factors that most affects the main cuts of birds, especially the breast and the thigh (Rosa et al., 2006). Studies with broilers affirm that males have higher breast than females, mainly due the reduction of meat deposition in breast at 42 days, when it's reached maturity, which does not occur in females (Mendes et al., 2003). Our results presented that male muscovy ducks had higher yields in almost all major commercial cuts.

All these information's are important to elaborate strategies for muscovy duck production in industrial scale, aiming to meet great consumer markets, such as China, Japan, France, Germany and others countries (Cruz et al., 2013; Minas State Journal, 2015).

\section{CONCLUSIONS}

The present study indicates that nutritional plan 3 (initial $=0.25 \%$; growth $=0.30 \%$ and termination $=0.35 \%$ ) showed better nutritional requirements of sodium for muscovy ducks in housing, obtaining better performance and carcass development.

\section{REFERENCES}

Almeida ECJ, Santos MRA, Farias Filho SRV, Hora FF, Oliveira EB, Pereira $A H R$, et al. Variabilidade fenotípica de características de carcaça do pato nativo comparada com linhagem comercial. Anais da $24^{\text {a }}$ Semana de Zootecnia da UFRPE; 2016; Recife, PE. Brasil; 2016.

Andriguetto JM, Perly L, Minardi JS, Gemae IA, Flemming JS, Souza GA, et al. Nutrição animal. 4thed. São Paulo: Nobel; 1990.

Borges SA, Ariki J, Jerônimo R, Martins CL, Moraes VMB. Níveis de cloreto de sódio em rações para frangos de corte. Arquivo Brasileiro Medicina Veterinária e Zootecnia 1998;50(5):619-624.

Borges SA, Laurentiz AC, Araújo LF, Araújo CSS, Maiorka A, Ariki J. Effect of crude protein and diferent balance eletrolytic of the diets on broilers performance during the starter period. Revista Brasileira de Ciência Avícola 2002;4(2):155-161.

Borges SA. Balanço eletrolítico e sua interrelação com o equilíbrio ácidobase em frangos de corte submetidos a estresse calórico [thesis]. Jaboticabal (SP): Universidade Estadual Paulista; 2001. 
Santos ANA, Cruz FGG, Oliveira Filho PA, Farias TM, Rufino JPF, Viana Filho GB
Sodium Requirement for Muscovy Ducks in Housing
Costa VR. Efeitos do nível energético da ração e do estresse térmico na expressão da proteína de choque térmico Hsp70 e nos níveis do seu mRNA no fígado de frangos de corte em diferentes estágios de desenvolvimento [dissertation]. Manaus (AM): Universidade Federal do Amazonas; 2018.

Dean WF, Price Jl, Leibovitz L. Effect of feed medicaments on bacterial infections in ducklings. Poultry Science 1973;52(2):549-558.

Drumond ESC, Gonçalves FM, Veloso RC, Amaral JM, Balotin LV, Pires AV, et al. Curvas de crescimento para codornas de corte. Ciência Rural 2013;43(10):1872-1877.

Feijó JC, Cruz FGG, Rufino JPF, Melo RD, Melo LD, Costa APGC, et al. Planos nutricionais com diferentes níveis de cálcio sobre o desempenho e rendimentos de carcaça de patos (Cairina moschata) em confinamento. Revista Científica de Avicultura e Suinocultura 2016;2(1): 11-20.

Gois FD, Almeida ECJ, Farias Filho RV, Silva Filha OL. Estudo preliminar sobre o dimorfismo sexual do pato cinza do catolé (Cairina moschata). Actas Ibero Americanas de Conservacion Animal 2012;2:95-98.

Gomide LAM, Alencar N, Macedo IA. Processamento de frango (corte, recorte e desossa). 2nd ed. Brasília: LK Editora; 2012.

Guyton AC, Hall JE. Tratado de fisiologia médica. Rio de Janeiro: Guanabara; 1997.

Guyton AC. Tratado de fisiologia médica. Rio de Janeiro: Guanabara \& Koogan; 1985.

Industrial poultry. Industrialização de patos e marrecos; 2005 [cited 2018 Nov 07]. Available from: goo.gl/WcQ4jj.

Mendes AA, Moreira J, Garcia RG. Qualidade da carne de peito de frango de corte. Revista Nacional da Qualidade da Carne 2003;28(317).

Mendes AA, Patrício IS. Controles, registros e avaliação do desempenho de frangos de corte. In: Mendes AA, Nääs IA, Macari M, editors. Produção de frangos de corte. Campinas: FACTA; 2004. p.323-336.

Minas State Journal. Carne de pato está em plena valorização, mas faltam criadores em Minas; 2015 [cited 2018 Nov 07]. Available from: https:// goo.gl/64i6E1.

Patience JFA. Review of the role of acid-base balance in amino acid nutrition. Journal of Animal Science 1990:68:398-408.
Pinheiro SFR, Sakomura NK, Nascimento DCN, Dourado LRB, Fernandes JBK, Thomaz MC. Níveis nutricionais de fósforo disponível para aves de corte ISA Label criadas em semiconfinamento. Brazilian Journal of Animal Science 2011;40(2):361-369.

Pinheiro SRF. Níveis de fósforo, de cálcio e de cloreto de sódio para aves de linhagem de crescimento lento criadas em sistema semiconfinado [thesis]. Jaboticabal (SP): Universidade Estadual Paulista; 2009.

Puls R. Mineral levels in animal health. Clearbrook: Sherpa International; 1988.

Rosa FC, Bressan MC, Bertechini AG, Fassani EJ, Oliveira e Vieira J, Faria $\mathrm{PB}$, et al. Efeito de métodos de cocção sobre a composição química e colesterol em peito e coxa de frangos de corte. Ciência e Agrotecnologia 2006;30(4):707-714.

Rosado AMS. Efeitos de coccidicidas ionofóricos sobre o desempenho e o balanço de eletrólitos em frangos de corte [dissertation]. Viçosa (MG): Universidade Federal de Viçosa; 1988.

Rostagno HS, Albino LFT, Donzele JL, Gomes PC, Oliveira RF, Lopes DC, et al. Tabelas brasileiras para aves e suinos: composição dos alimentos e requerimentos nutricionais. 3 ed. Viçosa: UFV; 2011.

Rostagno HS, Albino LFT, Hannas MI, Donzele JL, Sakomura NK, Costa FGP, et al. Tabelas brasileiras para aves e suinos: composição dos alimentos e requerimentos nutricionais. 4th ed. Viçosa: UFV; 2017.

Rufino JPF, Cruz FGG, Melo LD, Soares VM, Curcio UA, Damasceno JL, et al. Quality and sensory evaluation of meat of ducks (Cairina moschata) in confinement under different nutritional plans and housing densities. International Journal of Poultry Science 2015;14(1):44-48.

Rufino JPF, Cruz FGG, Oliveira Filho PA, Costa VR, Feijó JC, Rocha BL. Classificação taxonômica, diferenças fisiológicas e aspectos nutricionais de marrecos e patos no Brasil. Revista Científica de Avicultura e Suinocultura 2017;3(1):20-32.

Vieira SL. Considerações sobre as características de qualidade de carne de frango e fatores que podem afetá-la. Anais da $36^{\text {a }}$ Reunião Anual da Sociedade Brasileira de Zootecnia; 1999; Porto Alegre. RS, Brasil; 1999.

Yakubu A. Characterization of the local muscovy duck genetic resource of Nigeria and its potential for egg and meat production. World's Poultry Science Journal 2013;69(4):931-938. 